\title{
Suppression of L-Arginine-Induced Acute Necrotizing Pancreatitis in Rats by Metformin Associated with the Inhibition of Myeloperoxidase and Activation of Interleukin-10
}

\author{
Supresión de la Pancreatitis Necrotizante Aguda Inducida por L-Arginina en Ratas por \\ Metformina Asociada con la Inhibición de Mieloperoxidasa y Activación de Interleucina-10
}

Fahaid Al-Hashem

AL-HASHEM, F. Suppression of L-Arginine-induced acute necrotizing pancreatitis in rats by metformin associated with the inhibition of myeloperoxidase and activation of interleukin-10. Int. J. Morphol., 39(1):102-108, 2021.

SUMMARY: Acute pancreatitis is a frequent life-threatening inflammatory disease of the pancreas characterized by severe abdominal pain that lasts for days to weeks. We sought to determine whether the antidiabetic and anti-inflammatory drug, metformin can substantially protect against acute pancreatitis in an animal model of L-arginine-induced acute pancreatitis, and whether this is associated with the augmentation of the anti-inflammatory cytokine interleukin-10 (IL-10) and inhibition of the enzyme that promotes tissue damage, myeloperoxidase (MPO). Rats were either injected with two doses of the amino acid L-arginine ( 2.5 gm $/ \mathrm{kg}$; i.p., at one-hour intervals) before being sacrificed after 48 hours (model group) or were pretreated with metformin $(50 \mathrm{mg} / \mathrm{kg}$ ) daily for two weeks prior to Larginine injections and continued receiving metformin until the end of the experiment (protective group). Using microscopic examination of the pancreas and blood chemistry, we observed that L-arginine induced acute pancreatic injury. This is demonstrated by an enlarged pancreas with patchy areas of haemorrhage, vacuolated cytoplasm and pyknotic nuclei in the acini, disorganized lobular architecture with infiltration of inflammatory cells within the interlobular connective tissue (CT) septa, and the presence of congested blood vessels that were substantially ameliorated by metformin. Metformin also significantly $(\mathrm{p}<0.05)$ inhibited L-arginine-induced MPO, lactate dehydrogenase (LDH), and the inflammatory biomarker tumor necrosis factor alpha (TNF- $\alpha$ ). Whereas, metformin significantly ( $<<0.05)$ increased IL-10 levels that were inhibited by pancreatitis induction. We further demonstrated a significant $(\mathrm{p}<0.001)$ correlation between the scoring of the degree of pancreatic lobules damage tissue damage and the blood levels of TNF- $\alpha$, IL-10, LDH, and MPO. Thus, metformin effectively protects against L-arginine-induced acute pancreatitis, which is associated with the inhibition of MPO and augmentation of IL-10.

KEY WORDS: Acute pancreatitis; L-arginine; Metformin; MPO; IL-10; Rat model.

\section{INTRODUCTION}

Acute pancreatitis represents a significant challenge to the health community since (i) it can lead to systemic inflammation and multiple organs dysfunction syndromes; (ii) high mortality rate that can reach $50 \%$ in severe acute pancreatitis form; and (iii) there is no available drug of choice to treat pancreatitis (Leach et al.,1991; Czakó et al., 2000). In acute pancreatitis, activation of digestive proteinases caused autodigestion and inflammation of the pancreas, which can lead, in severe cases, to diffuse pancreatic necrosis and hemorrhage, leukocyte infiltration, and necrosis and apoptosis of pancreatic acinar cells (Ceppa et al., 2011). Furthermore, it is believed that many etiological factors contribute to this disease like the gallstone blocking the common bile duct, heavy alcohol consumption, direct trauma, adverse drug effects, virus, and sepsis and shock (Cho et al., 2015).

Experimental acute pancreatitis using animal models of the disease is very useful to thoroughly understand the pathophysiology of the disease and to test potential drugs and compounds to treat acute pancreatitis (Kui et al., 2015). L-arginine-induced acute pancreatitis 
in rats and mice is reported following an injection (intraperitoneal injections) of two doses $(2.5-4 \mathrm{gm} / \mathrm{kg})$ of the amino acid (Czakó et al.; Kui et al.). Nitric oxide synthase converts L-arginine to L-citrulline and nitric oxide (NO), and the fast reaction of NO with oxygen radicals yield a highly cytotoxic compound, peroxynitrite (ONOO) that induces nitrosative stress and hence tissue damage (Venardos et al., 2009). Also, L-arginine is hydrolyzed to L-ornithine and urea by the enzyme arginase, and Lornithine is reported to induce a severe type of acute pancreatitis in rats (Biczó et al., 2010). Furthermore, other agents such as ethanol and cerulein, the analogue of the hormone cholecystokinin were successfully used to induce acute pancreatitis in animal models, which is characterized by a dysregulation of the production and secretion of digestive enzymes, cytoplasmic vacuolization and the death of acinar cells, edema formation, and infiltration of inflammatory cells into the pancreas (Pandol et al., 2003; Kim, 2008).

Metformin is widely used to treat type 2 diabetes mellitus (T2DM) (Cicero et al., 2012). It also ameliorates several types of liver diseases such as nonalcoholic fatty liver disease (NAFLD), improving liver injury in T2DM with hyperlipidaemia (Matafome et al., 2011), and protection of primary rat hepatocytes against oxidative stress-induced apoptosis (Conde de la Rosa et al., 2015). Metformin was also reported to inhibit the progression of pancreatic cancer (Xin et al., 2017) in addition to the antiinflammatory (Al-Hashem et al., 2019) and antioxidant (Dallak et al., 2019) effects of metformin. However, the potential protective effect of metformin on L-arginineinduced acute pancreatitis in rats has not been investigated before. Therefore, we speculated that the induction of acute pancreatitis by L-arginine in a rat model of the disease could beinhibited with metformin.

\section{MATERIAL AND METHOD}

Animals. All experimental procedures were approved by the medical research ethical committee at King Khalid University and according to the Guide for the Care and Use of Laboratory Animals published by the US National Institutes of Health (NIH publication No.85-23, revised 1996). Wistar rats (total 18 rats) weighing 150-200 g were used for these studies. All rats were bred and housed in the research center of King Khalid University, College of Medicine (Abha, Saudi Arabia), at temperatures of $23 \pm 1$ ${ }^{\circ} \mathrm{C}$ and a $12 \mathrm{~h}$ light: $12 \mathrm{~h}$ dark cycle. Rats had free access to tap water and fed standard laboratory chow during the acclimatization period.
Experimental design. After a one week adaptation period, rats were randomly assigned into 3 groups $(n=6$; each) and were distributed in their corresponding cages and classified as follows: Control group (Control): nontreated rats that were injected intraperitoneally with vehicle; L-arginine-treated group, the model group (L-arg): rats were injected intraperitoneally on day 15 with $2.5 \mathrm{gm} /$ $\mathrm{kg}$ L-arginine, $2 \mathrm{x}$ in an at 1-hour intervals (Czakó et al.). They received no treatment (vehicle) in the first two weeks; and the protective group (Met $+\mathrm{L}-\mathrm{arg}$ ): rats were treated with metformin $(50 \mathrm{mg} / \mathrm{kg})$ from day 1 - day 17 and injected on day 15 with $2.5 \mathrm{gm} / \mathrm{kg}$ L-arginine, $2 \mathrm{x}$ within one hour. At the end of experimental period (on day 17), blood samples were collected by cardiac puncture under anaesthesia (sodium thiopental at $40 \mathrm{mg} / \mathrm{kg}$ body weight), and animals were then culled and tissues were harvested. Blood samples were collected without anticoagulant, left for 10 minutes, then centrifuged for 10 minutes at $4000 \mathrm{r} /$ min to obtain serum, which was stored at $-20{ }^{\circ} \mathrm{C}$ until further biochemical analysis.

Histological examination. Pancreas from all rats were collected and fixed in $10 \%$ formol saline for 24 hours prior to dehydration with alcohols and paraffin embedding using standard methods. Blocks were processed, sectioned in $5 \mathrm{~mm}$ thickness and subjected to $\mathrm{H} \& \mathrm{E}$ staining to observe the morphological changes (Al-Hashem et al.).

\section{Determination of blood levels of LDH, MPO, TNF- $\alpha$,} and IL-10. At day 17, animals were sacrificed and serum levels of LDH (Abcam, Cambridge, UK), MPO (EagleBio, NH, USA), TNF- $\alpha$ (Abcam, Cambridge, UK), and IL-10 (RayBio, GA, USA) were determined using ELISA kits according to the manufacturer's instructions.

Statistical and morphometric analysis. The data were expressed as mean \pm standard deviation (SD). Data were processed and analyzed using the SPSS version 10.0 (SPSS, Inc., Chicago, Ill., USA). One-way ANOVA was performed followed by Tukey's post hoc test. Pearson correlation statistical analysis was done for detection of a probable significance between two different parameters. Results were considered significant if $\mathrm{p} \leq 0.05$.

Using "Leica Qwin 500 C" image analyzer (Cambridge, UK), the degree of pancreatic lobules damage were obtained in 10 non overlapping high power fields/ rat of H\&E-stained sections. Quantitative data were tabulated as a means and standard deviations (SD) and compared using analysis of variance (ANOVA) followed by post-hoc analysis (Tukey test). A significant difference was considered when P-value $\leq 0.05$. Calculations were made on SPSS software (version 19). 


\section{RESULTS}

Metformin protects against $\mathbf{L}$-arg-induced acute pancreatic injury. To assess the effect of metformin treatment on the protection against L-arg-induced acute pancreatitis using histological investigations, the protective group of rats was pretreated for two weeks with metformin before L-arg injections and continued receiving metformin until the end of the experiment. Explanted pancreases from all animal groups were examined and pancreas tissues were prepared for basic histology staining. Compared to normal macroscopic images in the control group of rats (Fig. 1A, I), L-arg induced swelling with patchy areas of haemorrhage (Fig. 1A, II). Metformin treatment (Fig. 1A, III) preserved the pancreas morphological structure by inhibiting L-arginduced damaged pancreases. Representative $\mathrm{H} \& \mathrm{E}$ images of the pancreatic tissue obtained from the control group of rats (Fig. 1B, I) showing the regular architecture of pancreatic tissue as demonstrated by multiple lobules separated by thin connective tissue (CT) septa, with each lobule forming multiple acini lined with pyramidal cells. These cells show basal rounded pale nuclei, basal basophilic cytoplasm, and apical acidophilic granules. H \&E image represents pancreatic sections of the model group (L-arg) of rats (Fig.
1B, II) which shows disorganized lobular architecture with inflammatory infiltration within the CT septa. The acini appear with multiple cytoplasmic vacuolations and pyknotic nuclei. In addition, the presence of congested blood vessels and extra-vasated blood in between the acini are revealed.

Metformin treatment (Met+L-arg) substantially but not completely preserved pancreas architecture (Figs. 1B, III and 1C) as demonstrated by re-appearance of the pancreatic lobules $(\mathrm{L})$ which are separated by a thin $\mathrm{CT}$ septa (*). Pancreatic tissues showed regression of inflammatory changes. The acini (A) appear nearly normal except for the presence of a few cytoplasmic vacuolations (v) and some pyknotic nuclei (arrows). Congested blood vessels (bv) are also seen. Furthermore, quantification of pancreas damage demonstrated an effective $(p<0.05)$ inhibition of pancreatic lobules damage by metformin (Fig. 1C).

Metformin inhibits L-arg-induced inflammation. The link between inflammation and acute pancreatitis is well established (Czakó et al.). To investigate whether the observed protection of pancreatic injury was also associated with the inhibition of inflammation, we measured the inflammatory biomarker TNF- $\alpha$ and the anti-inflammatory biomarker IL-10 in serum samples collected from the
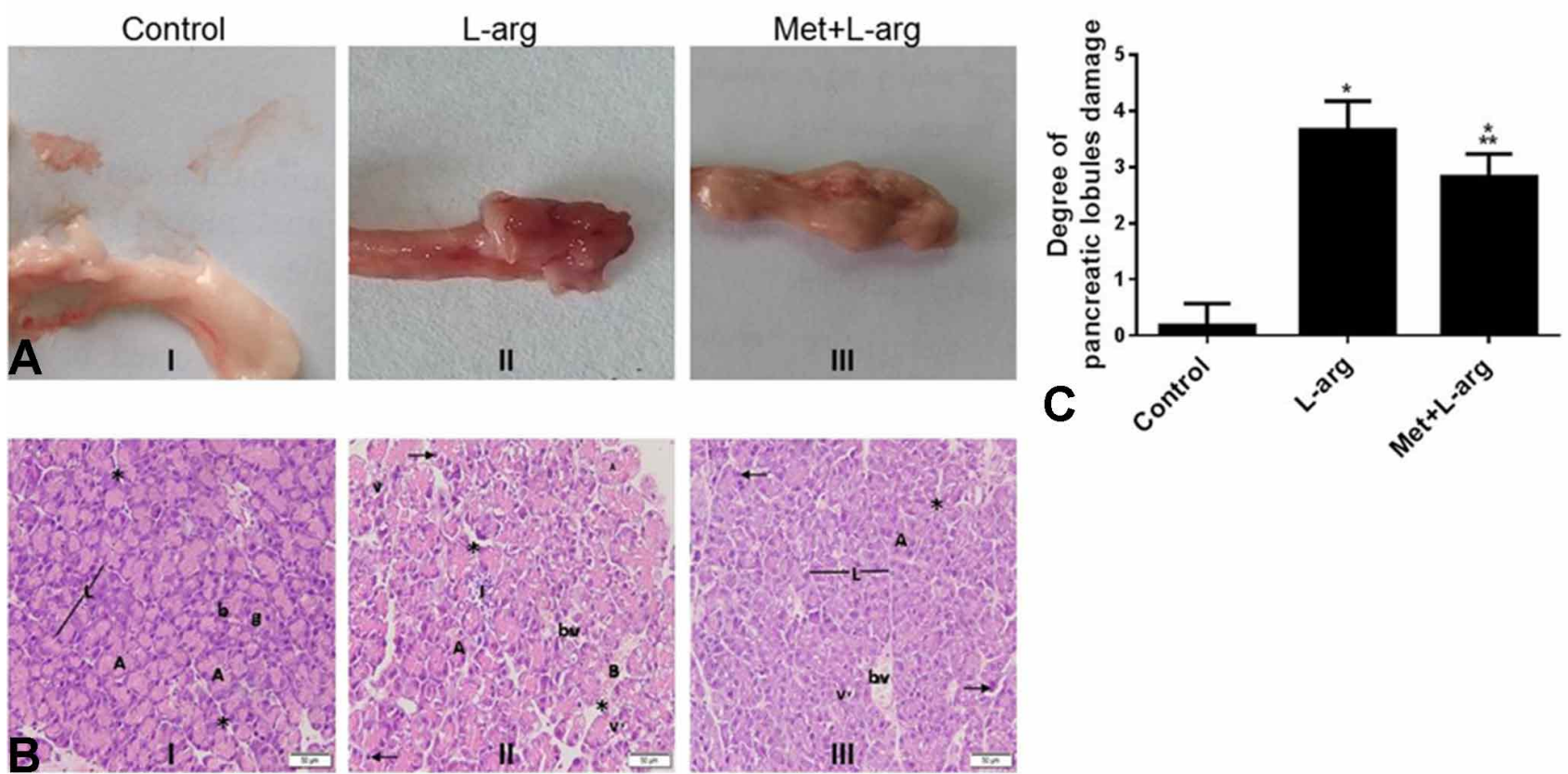

Fig. 1. Metformin protects pancreatic tissue against injury induced by L-arg. Macroscopic images of explanted pancreases (A) from the control group (I), L-arg group (II), and Met+L-arg group (III) of rats are depicted. (B). H\&E images (x200) of harvested tissues obtained from the pancreas of the control group (I), L-arg group (II), and Met+L-arg group (III) of rats are visualized by light microscopy. Note that arrows in (II) and (III) point to pyknotic nuclei, and the (*) points to the CT septa. H \& E: hematoxylin and eosin; L: lobules; A: acini; I: infiltrated inflammatory cells; b: basophilic cytoplasm; g: acidophilic granules; v: vacuoles; bv: congested blood vessels; B: extravasated blood. (C). Histological quantification of pancreatic lobules in the groups mentioned above. All shown p values are significant; $* \mathrm{p}<0.05$ versus control and $* * \mathrm{p}<0.05$ versus L-arg. 
metformin treated (Met+L-arg), L-arg and control groups 2 days after the induction of pancreatitis (Fig. 2). Metformin treatment significantly $(\mathrm{p}<0.05)$ (i) reduced L-arg-induced TNF- $\alpha$ (Fig. 2A); and induced IL-10 (Fig. 2B). However, the level of these parameters in the Met+L-arg group was significantly elevated compared with the control group of rats. This means partial protection by metformin was achieved.
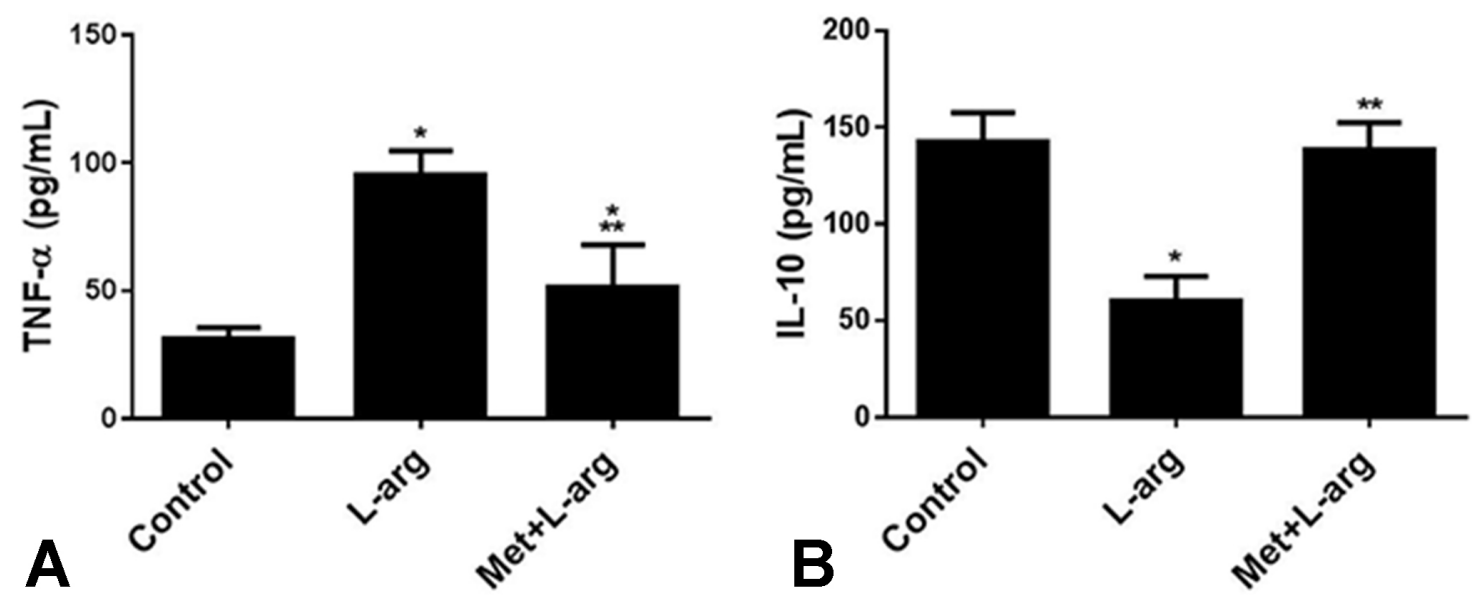

Fig. 2. Metformin protects the levels of inflammatory and anti-inflammatory biomarkers modulated by L-arg. Blood levels of TNF- $\alpha$ (A) and IL-10 (B) were measured at the end of the experiment in all groups of rats; Control, L-arg, and Met+L-arg groups. Results represent the mean $( \pm \mathrm{SD}) ; \mathrm{n}=6$ for each group. Experiments were performed in triplicate. All shown $\mathrm{p}$ values are significant; $* \mathrm{p}<0.05$ versus control and $* * \mathrm{p}<0.05$ versus $\mathrm{L}$-arg.

Metformin inhibits L-arg-induced biomarkers of tissue necrosis. To investigate whether the observed protection to pancreatic tissues and inflammation in the L-arg injected rats pretreated with metformin shown above was also associated with the inhibition of biomarkers of tissue necrosis, we measured blood LDH and MPO in the metformin-treated group (Met+L-arg) and compared it to the L-arg and control groups 2 days after the induction of pancreatitis (Fig. 3). Metformin treatment significantly $(\mathrm{p}<0.05)$ reduced L-arg-induced LDH (Fig. 3A) and MPO (Fig. 3B). However, the level of these parameters in the Met+L-arg group was significantly elevated compared with the control group of rats. This means partial protection by metformin was achieved.
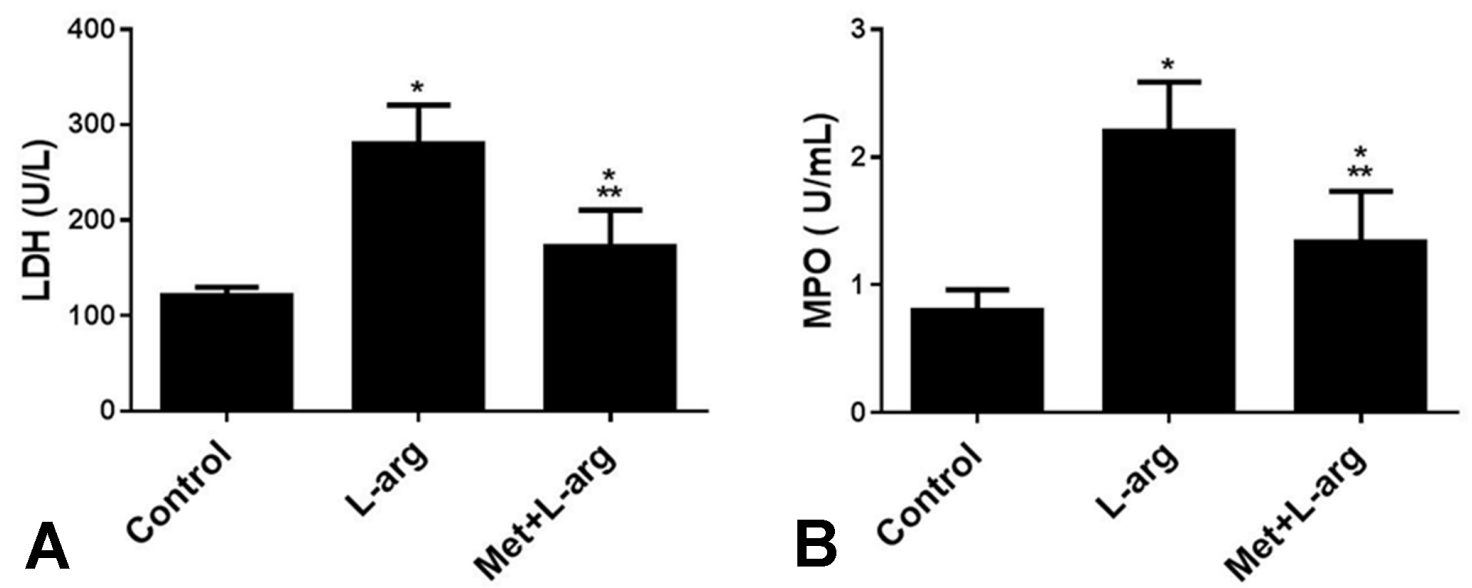

Fig. 3. Metformin inhibits biomarkers of tissue necrosis induced by L-arg. Blood levels of LDH (A) and MPO (B) were measured at the end of the experiment in all groups of rats; Control, L-arg, and Met+L-arg groups. Results represent the mean $( \pm \mathrm{SD}) ; \mathrm{n}=6$ for each group. Experiments were performed in triplicate. All shown $\mathrm{p}$ values are significant; $* \mathrm{p}<0.05$ versus control and $* * \mathrm{p}<0.05$ versus L-arg. 
Correlation between pancreatic tissue injury and biomarkers of inflammation and necrosis. We determined the correlation between the scoring of pancreas tissue damage and the blood levels of inflammation and necrosis biomarkers in order to further confirm and characterize that the role of metformin is stable and an appropriate agent in pancreatic injury in rats, and to further support the link between pancreatic injury and inflammation and necrosis. As shown in Figures 4A-C, a positive correlation was scored between pancreatic lobules damage scoring and these biomarkers; TNF- $\alpha(r=0.777)(p=0.0001), \mathrm{LDH}(\mathrm{r}=0.807)(\mathrm{p}<0.0001)$, and MPO $(r=0.765)(p=0.0002)$, respectively. Whereas, a negative correlation was shown between pancreatic lobules damage scoring and IL-10 $(\mathrm{r}=0.670)(\mathrm{p}=0.0024)($ Fig. 4D $)$.
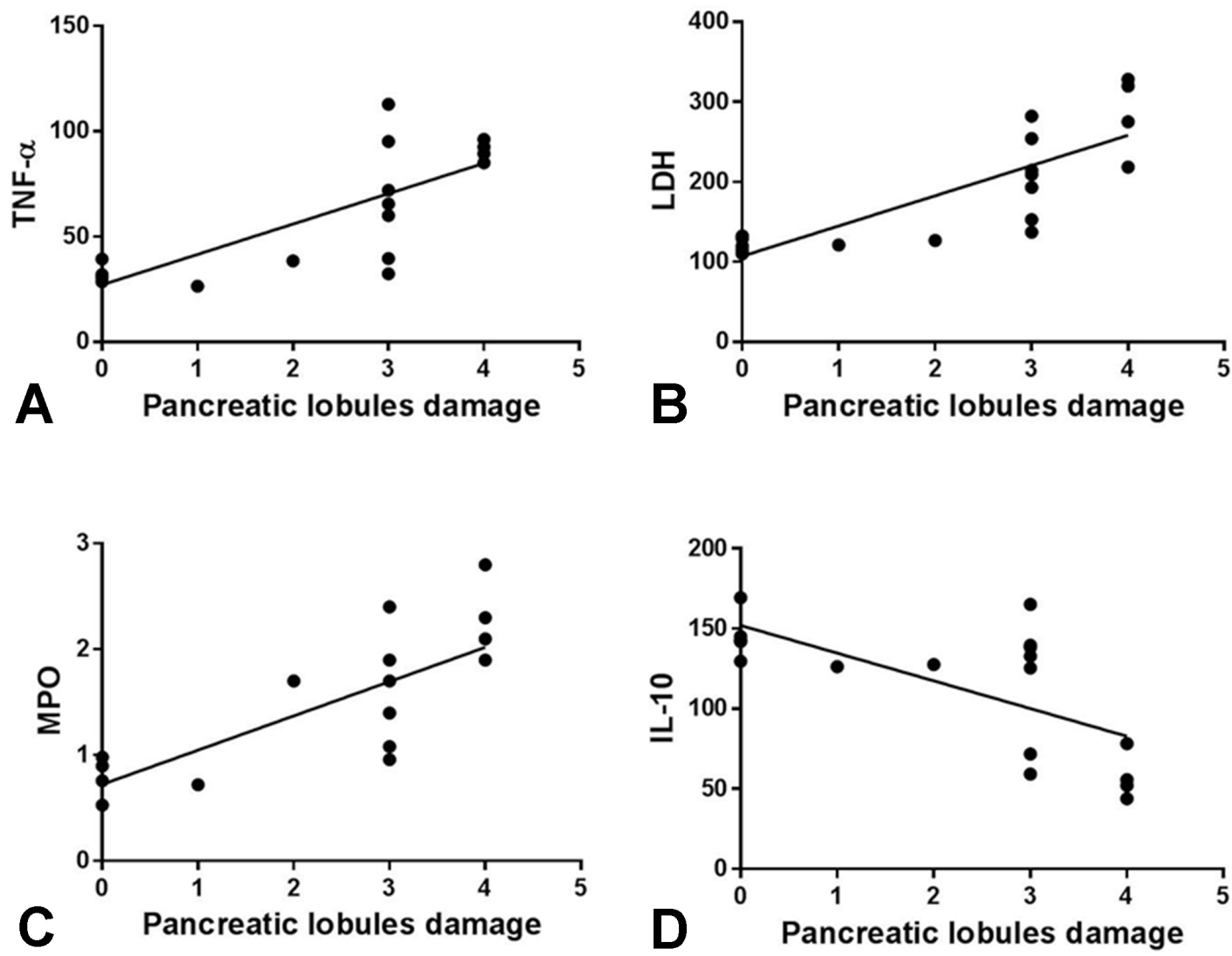

Fig. 4. Correlation between pancreatic tissue injury scoring and biomarkers of acute pancreatic injury. Degree of pancreatic lobules injury was assessed in all groups of rats at the end of the experiment and the relationship between pancreatic injury and TNF- $\alpha$ (A), LDH (B), MPO (C), and IL-10 (D) is shown.

\section{DISCUSSION}

The main findings in this study were that in a rat model of acute pancreatitis toxic doses of L-arg induced pancreatic tissue injury and modulated the assessed biomarkers of inflammation, anti-inflammation, and tissue necrosis. In addition, the antidiabetic and anti-inflammatory drug metformin substantially protected against these parameters induced by L-arg, including tissue injury. These conclusions are supported by the data indicating that L-arginduced acute necrotizing pancreatitis (Fig. 1), caused upregulation of TNF- $\alpha, \mathrm{LDH}$, and MPO, and inhibition of
IL-10 (Figs. 2 and 3) that were substantially but not completely protected by metformin (Figs. 1-3). Also, our data that shows a significant correlation between tissue injury scoring and the blood levels of TNF- $\alpha, \mathrm{LDH}, \mathrm{MPO}$, and IL10 (Figs. 4A-C) supports our conclusion mentioned above. Our results were thus consistent with our working hypothesis that the antidiabetic and anti-inflammatory drug, metformin, can substantially protect against L-arg-induced pancreatic injury in rats, which is associated with the inhibition of inflammation and MPO. 
Inflammation and tissue necrosis are known to be involved in the pathology of acute pancreatitis in humans and in animals injected with L-arg and cerulean (Hegyi et al., 2004; Kim). The inflammatory cytokine TNF- $\alpha$ and biomarkers of tissue necrosis, MPO and LDH are augmented upon acute pancreatic injury. This was reported to provide a functional link between inflammation, necrosis, and severe acute pancreatitis (Wang et al., 2017; Uhl et al., 1991). Whereas, the antiinflammatory cytokine IL-10 was reported to be ameliorated in patients with severe acute pancreatitis (Pezzilli et al., 1997), and the severity of acute pancreatitis is higher in knock-out mice for IL-10 (Gloor et al., 1998). In addition, metformin was reported to (i) inhibit pathological inflammation in the liver (AlHashem et al.) and gut (Di Fusco et al., 2018); (ii) inhibits MPO activity in isoproterenol-induced cardiomyocyte necrosis (Soraya et al., 2015); and (iii) inhibits liver and kidney tissue injuries (Corremans et al., 2019; AlHashem et al.). Furthermore, the anti-inflammatory compound resveratrol was reported to inhibit L-arginduced acute necrotizing pancreatitis (Wang et al.). These reports are in agreement with our findings of elevated levels of TNF- $\alpha$, MPO, and LDH, and inhibiting levels of IL-10 in L-arg-induced acute liver injury, which were protected with metformin. However, metformin was reported to induce $\mathrm{LDH}$ as a side-effect of the drug in patients with metformin-associated lactic acidosis (Yeh et al., 2017) and not decreased it as we reported here.

In conclusion, using basic histological staining and blood chemistry, we demonstrate the development of acute necrotizing pancreatitis induced by L-arg in a rat model, which is significantly protected by metformin. We also demonstrated an association between pancreatic injury and biomarkers of inflammation and tissue necrosis.

\section{ACKNOWLEDGEMENTS}

The author would like to thank Professors Bahjat Al-Ani and Mohamed A. Haidara from the Department of Physiology, College of Medicine, King Khalid University, Abha, Saudi Arabia, and Dr. Samaa S. Kamar from the Medical Histology, Kasr Al-Aini Faculty of Medicine, Cairo University, Cairo, Egypt for their input and help during the preparation of this manuscript. Also, the author would like to thank Dr. Mariam Al-Ani from Dental Care Partnership, Sutton Coldfield, Birmingham, UK for proofreading the manuscript.
AL-HASHEM, F. Supresión de la pancreatitis necrotizante aguda inducida por L-arginina en ratas por metformina asociada con la inhibición de mieloperoxidasa y activación de interleucina-10. Int. J. Morphol., 39(1):102-108, 2021.

RESUMEN: La pancreatitis aguda es una enfermedad inflamatoria del páncreas que amenaza la vida y se caracteriza por un dolor abdominal intenso que dura de días a semanas. Buscamos determinar si la metformina, fármaco antidiabético y antiinflamatorio, puede proteger contra la pancreatitis aguda en un modelo animal de pancreatitis aguda inducida por L-arginina. Además se estudió la asociación con el aumento de la citocina antiinflamatoria interleucina-10. (IL-10) e inhibición de la enzima que promueve el daño tisular, mieloperoxidasa (MPO). Las ratas se inyectaron con dos dosis del aminoácido L-arginina (2,5 $\mathrm{g} / \mathrm{kg}$; ip, a intervalos de una hora) antes de ser sacrificadas después de 48 horas (grupo modelo) o se pre trataron con metformina $(50 \mathrm{mg} / \mathrm{kg}$ ) durante dos semanas antes del tratamiento de Larginina y continuaron recibiendo metformina hasta el final del experimento (grupo protector). Mediante el examen microscópico del páncreas y la química sanguínea, se observó que la Larginina inducía una lesión pancreática aguda. Se observó un aumento significativo de tamaño del páncreas con áreas hemorrágicas, citoplasma vacuolado y núcleos picnóticos en los acinos, arquitectura desorganizada con infiltración de células inflamatorias dentro de los tabiques del tejido conjuntivo interlobulillar (TC) y la presencia de vasos sanguíneos congestionados mejorados por metformina. Se observó que la metformina inhibió significativamente $(\mathrm{p}<0,05)$ la MPO inducida por Larginina, la lactato deshidrogenasa (LDH) y el factor de necrosis tumoral alfa $(\mathrm{TNF}-\alpha)$. Además, demostramos una correlación significativa ( $\mathrm{p}<0,001)$ entre la puntuación del grado de daño tisular de los lóbulos pancreáticos y los niveles sanguíneos de TNF- $\alpha$, IL-10, LDH y MPO. Por tanto, la metformina protege eficazmente contra la pancreatitis aguda inducida por L-arginina, que se asocia con la inhibición de MPO y el aumento de IL-10.

PALABRAS CLAVE: Pancreatitis aguda; L-arginina; Metformina; MPO; IL-10; Modelo de rata.

\section{REFERENCES}

Al-Hashem, F.; Al-Humayed, S.; Amin, S. N.; Kamar, S. S.; Mansy, S. S.; Hassan, S.; Abdel-Salam, L. O.; Ellatif, M. A.; Alfaifi, M.; Haidara, M. A.; et al. Metformin inhibits mTOR-HIF-1a axis and profibrogenic and inflammatory biomarkers in thioacetamide-induced hepatic tissue alterations. J. Cell Physiol., 234(6):9328-37, 2019.

Biczó, G.; Hegyi, P.; Berczi, S.; Dósa, S.; Hracskó, Z.; Varga, I. S.; Iványi, B.; Venglovecz, V.; Wittmann, T.; Takács, T.; et al. Inhibition of arginase activity ameliorates L-arginine-induced acute pancreatitis in rats. Pancreas, 39(6):868-74, 2010.

Ceppa, E. P.; Lyo, V.; Grady, E. F.; Knecht, W.; Grahn, S.; Peterson, A.; Bunnett, N. W.; Kirkwood, K. S. \& Cattaruzza, F. Serine proteases mediate inflammatory pain in acute pancreatitis. Am. J. Physiol. Gastrointest. Liver Physiol., 300(6):G1033-42, 2011.

Cho, J. H.; Kim, T. N. \& Kim, S. B. Comparison of clinical course and outcome of acute pancreatitis according to the two main etiologies: alcohol and gallstone. BMC Gastroenterol., 15:87, 2015. 
Cicero, A. F. G.; Tartagni, E. \& Ertek, S. Metformin and its clinical use: new insights for an old drug in clinical practice. Arch. Med. Sci., 8(5):90717, 2012.

Conde de la Rosa, L.; Vrenken, T. E.; Buist-Homan, M.; Faber, K. N. \& Moshage, H. Metformin protects primary rat hepatocytes against oxidative stress-induced apoptosis. Pharmacol. Res. Perspect., 3(2):e00125, 2015.

Corremans, R.; Vervaet, B. A.; D'Haese, P. C.; Neven, E. \& Verhulst, A. Metformin: a candidate drug for renal diseases. Int. J. Mol. Sci., 20(1):42, 2019.

Czakó, L.; Takács, T.; Varga, I. S.; Hai, D. Q.; Tiszlavicz, L.; Hegyi, P.; Mándi, Y.; Matkovics, B. \& Lonovics, J. The pathogenesis of L-arginine-induced acute necrotizing pancreatitis: inflammatory mediators and endogenous cholecystokinin. J. Physiol. Paris, 94(1):43-50, 2000.

Dallak, M.; Haidara, M. A.; Bin-Jaliah, I.; Eid, R. A.; Amin, S. N.; Abdel Latif, N. S. \& Al-Ani, B. Metformin suppresses aortic ultrastrucural damage and hypertension induced by diabetes: a potential role of advanced glycation end products. Ultrastruct. Pathol., 43(4-5):190-8, 2019.

Di Fusco, D.; Dinallo, V.; Monteleone, I.; Laudisi, F.; Marafini, I.; Franzè, E.; Di Grazia, A.; Dwairi, R.; Colantoni, A.; Ortenzi, A.; et al. Metformin inhibits inflammatory signals in the gut by controlling AMPK and p38 MAP kinase activation. Clin. Sci. (Lond.), 132(11):1155-68, 2018.

Gloor, B.; Todd, K. E.; Lane, J. S.; Rigberg, D. A. \& Reber, H. A. Mechanism of increased lung injury after acute pancreatitis in IL-10 knockout mice. J. Surg. Res., 80(1):110-4, 1998.

Hegyi, P.; Rakonczay Jr., Z.; Sári, R.; Góg, C.; Lonovics, J.; Takács, T. \& Czakó, L. L-arginine-induced experimental pancreatitis. World $J$. Gastroenterol., 10(14):2003-9, 2004.

Kim, H. Cerulein pancreatitis: oxidative stress, inflammation, and apoptosis. Gut Liver, 2(2):74-80, 2008.

Kui, B.; Balla, Z.; Vasas, B.; Végh, E. T.; Pallagi, P.; Kormányos, E. S.; Venglovecz, V.; Iványi, B.; Takács, T.; Hegyi, P.; et al. New insights into the methodology of L-arginine-induced acute pancreatitis. PLoS One, 10(2):e0117588, 2015.

Leach, S. D.; Modlin, I. M.; Scheele, G. A. \& Gorelick, F. S. Intracellular activation of digestive zymogens in rat pancreatic acini. Stimulation by highdoses of cholecystokinin. J. Clin. Invest., 87(1):362-6, 1991.

Matafome, P.; Louro, T.; Rodrigues, L.; Crisóstomo, J.; Nunes, E.; Amaral, C.; Monteiro, P.; Cipriano, A. \& Seiça, R. Metformin and atorvastatin combination further protect the liver in type 2 diabetes with hyperlipidaemia. Diabetes Metab. Res. Rev., 27(1):54-62, 2011.

Pandol, S. J.; Gukovsky, I.; Satoh, A.; Lugea, A. \& Gukovskaya, A. S. Animal and in vitro models of alcoholic pancreatitis: role of cholecystokinin. Pancreas, 27(4):297-300, 2003.

Pezzilli, R.; Billi, P.; Miniero, R. \& Barakat, B. Serum interleukin-10 in human acute pancreatitis. Dig. Dis. Sci., 42(7):1469-72, 1997.

Soraya, H.; Rameshrad, M.; Mokarizadeh, A. \& Garjani, A. Metformin attenuates myocardial remodeling and neutrophil recruitment after myocardialinfarction in rat. Bioimpacts, 5(1):3-8, 2015.

Uhl, W.; Büchler, M.; Malfertheiner, P.; Martini, M. \& Beger, H. G. PMNelastase in comparison with CRP, antiproteases, and LDH as indicators of necrosis in human acute pancreatitis. Pancreas, 6(3):253-9, 1991.

Venardos, K.; Zhang, W. Z.; Lang, C. \& Kaye, D. M. Effect of peroxynitrite on endothelial L-arginine transport and metabolism. Int. J. Biochem. Cell Biol., 41(12):2522-7, 2009.

Wang, N.; Zhang, F.; Yang, L.; Zou, J.; Wang, H.; Liu, K.; Liu, M.; Zhang, H.; Xiao, X. \& Wang, K. Resveratrol protects against L-arginine-induced acute necrotizing pancreatitis in mice by enhancing SIRT1-mediated deacetylation of p53 and heat shock factor 1. Int. J. Mol. Med., 40(2):42737, 2017.

Xin, W.; Fang, L.; Fang, Q.; Zheng, X. \& Huang, P. Effects of metformin on survival outcomes of pancreatic cancer patients with diabetes: A metaanalysis. Sci. Rep., 8(3):483-8, 2018.

Yeh, H. C.; Ting, I. W.; Tsai, C. W.; Wu, J. Y. \& Kuo, C. C. Serum lactate level and mortality in metformin-associated lactic acidosis requiring renal replacement therapy: a systematic review of case reports and case series. BMC Nephrol., 18:229, 2017.
Corresponding author:

Professor Fahaid Al-Hashem

Department of Physiology

College of Medicine

King Khalid University

Abha 61421

SAUDI ARABIA

E-mail: fahaid999@yahoo.com

Received: 07-08-2020

Accepted: 10-09-2020 